\title{
Venetia megacrysts, Northern Province, South Africa
}

Rodionov, A.S. Viljoen, K.S.

Anglo American Research Laboratories (PTY) Ltd, P.O. Box 106, Crown Mines, 2025, South Africa

Only discrete garnet nodules were found as megacrysts in the Venetia kimberlites so far ${ }^{1}$ A collection of 129 garnet nodules was collected by one of the authors (KSV) from tailings at the Venetia mine.

The megacrysts vary in size from 1 to $3 \mathrm{~cm}$. About $25 \%$ of the grains contain altered silicate inclusions, $8 \%$ - clinopyroxene inclusions, $7.5 \%$ - ilmenite inclusions and about $5 \%$ - both ilmenite and clinopyroxene.

Microprobe analysis revealed a presence of two compositionally distinctive types of garnets: (L) typical for the other RSA kimberlites low-Cr and moderate-Ca lherzolitic group (e.g. Monastery mine. Moore, 1986) , and (W) - low-Cr and elevated Ca wehrlitic group. Group (W) was never before found in the RSA kimberlites. First description of these unusual megacrysts found in Dalnaya pipe (Yakutia) was previously done by A. Rodionov with co-authors (Rodionov, 1988, Rodionov et al.. 1988. 1989).

Another unusual characteristics of the Venetia garnet megacrysts is in the lack of grains with $\mathrm{Cr}_{2} \mathrm{O}_{3}$ content below $0.63 \mathrm{wt} . \%$.

Comparison of garnet chemistry with Monastery and Dalnaya showed, that

- Venetia. megacryst suite is unique for RSA.

- Garnet compositions are more close to the Dalnaya kimberlite (Yakutia) rather than to Monastery.

- At the same time Venetia megacrysts show clearly distinctive compositional patterns, especially on $\mathrm{Cr}_{2} \mathrm{O}_{3}-\mathrm{TiO}_{2}$ and $\mathrm{mg} \#-\mathrm{TiO}_{2}$ plots (Fig. 1B, 1C).

Ilmenites found as inclusions in Venetia garnet megacrysts are unusually high in $\mathrm{Cr}_{2} \mathrm{O}_{3}$ and moderate to high in $\mathrm{MgO}$ if compared to the Monastery suite. With exception of $\mathrm{Cr}_{2} \mathrm{O}_{3}$ all ilmenites have relatively tight clustering on all plots. Oxide concentrations vary as follows (wt. \%): $\mathrm{TiO}_{2}-52.5$ 55.5. $\mathrm{FeO}-28.6-32.4 . \mathrm{MgO}-9.06-12.4 . \mathrm{Al}_{2} \mathrm{O}_{3}-0.51-0.87$. Ilmenites split in two groups in terms of $\mathrm{Cr}_{2} \mathrm{O}_{3}$ content. One group has $1.03-1.28$ wt. $\% \mathrm{Cr}_{2} \mathrm{O}_{3}$ and another $-2.02-2.47$ wt. $\%$ of $\mathrm{Cr}_{2} \mathrm{O}_{3}$ Variations for $\mathrm{Cr}_{2} \mathrm{O}_{3}$ and $\mathrm{MgO}$ for Monastery are $0.00-0.42$ and 7.78 - 10.6 (wt. \%) respectively. Ilmenites from Dalnaya megacrysts suite cover a wider compositional range than both Venetia and Monastery.

Clinopyroxene inclusion chemistry does not reveal any surprises and is comparable to other welldescribed cases. When compared to the Monastery megacrysts, Venetia clinopyroxenes are higher in magnesium (both in association with ilmenite and without the one) and do not reach so high temperatures as some discrete nodules from Monastery.

Some indications of chemical disequilibrium between ilmenite inclusions and hosting garnet were observed. At equilibrium conditions, $\mathrm{Cr}_{2} \mathrm{O}_{3}$ content in garnet and ilmenite has to be the same (Green. Sobolev, 1975). $\mathrm{Cr}_{2} \mathrm{O}_{3}$ (garnet) $-\mathrm{Cr}_{2} \mathrm{O}_{3}$ (ilmenite) plot reveals significant scattering off the "equilibrium" line $(r=1.0)$. This can be interpreted as an indication of relatively high growth rate of the megacrysts in question.

\footnotetext{
'It has to be noted that few compositionally megacrystic ilmenites and clinopyroxenes were found in concentrate.
} 
Three models are possible in principle to explain the above observations:

1. Two independent melts evolution.

2. Metasomatic interaction of a single melt with two rock types (lherzolites and eclogites or wehrlites).

3. Melt mixing.

It is concluded that the melt mixing model seems to be the best choice. The sequence of events could be as follows:

1st stage - crystallisation of high-T discrete nodules (with some silicate inclusions).

2nd stage - "normal" megacryst crystallisation trend (L-type) with accumulating $\mathrm{TiO}_{2}, \mathrm{FeO}$, $\mathrm{CaO}$ and depletion in $\mathrm{Cr}_{2} \mathrm{O}_{3}$ and $\mathrm{MgO}$. It almost reached a stage of ilmenite appearance as a new phase.

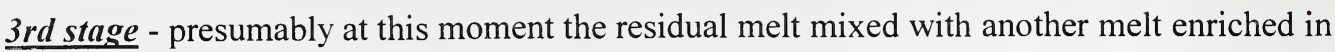
$\mathrm{CaO}$ and $\mathrm{FeO}$ (eclogitic/basaltic type ?), but not saturated in $\mathrm{TiO}_{2}$. The paragenesis changes to W-type. Nucleation of ilmenite (inclusions) begins. Presumably mixing did not happen immediately in the whole of the chamber volume, since some garnet points plot on continuation of the same trend. Alternatively, crystal fractionation could play some role. Continued inflow of high-Ca melt results in massive clinopyroxene plus garnet crystallisation. The additional volumes of garnet and clinopyroxene "consumed" or dissolved accumulated in the melt $\mathrm{TiO}_{2}$ and the ilmenite nucleation interrupted. Oversaturation in $\mathrm{Ca}$ and $\mathrm{FeO}$ results in relatively high rate of crystal growth, which is recorded in some disequilibrium signatures discussed above.

Venetia megacryst suite never reached the stage of an extensive ilmenite crystallisation. Presumably, there should be abundant clinopyroxene megacrysts, which are entirely altered and did not preserve in the tailings. Minor element chemistry study is required to support or reject the suggested model.

\section{References}

1. Green, D.H., Sobolev N.V., (1975). Coexisting garnets and ilmenites synthesised at high pressures and temperatures from pyrolite and olivine basanite and their significance for kimberlitic assemblages. Contrib. Mineral. and Petrol., v. 50, pp. 217-229.

2. Moore, R.O., (1986). A study of the kimberlites, diamonds and associated rocks in minerals from the Monastery mine, South Africa. Ph.D. thesis, UCT, RSA.

3. Rodionov, A.S., (1988). Ilmenite peridotite xenoliths with zoned garnets from Dalnaya kimberlite pipe (Yakutia). In: Ultramafic paragenesis minerals from kimberlites and conditions of their genesis, Novosibirsk, pp. 86-94. (In Russian).

4. Rodionov, A.S., Pokhilenko, N.P., Amshinsky, A.N., (1988). Ilmenite-pyrope wehrlites - new type of paragenesis in xenoliths from kimberlite. Geologia i geofizika, No.7, pp.53-57. (In Russian).

5. Rodionov, A.S., Pokhilenko, N.P., Amshinsky, A.N., (1989). Megacryst suite in Yakutian kimberlites: new data. In: Problems of kimberlite magmatism, Novosibirsk, Nauka, pp. 120-126. (In Russian). 

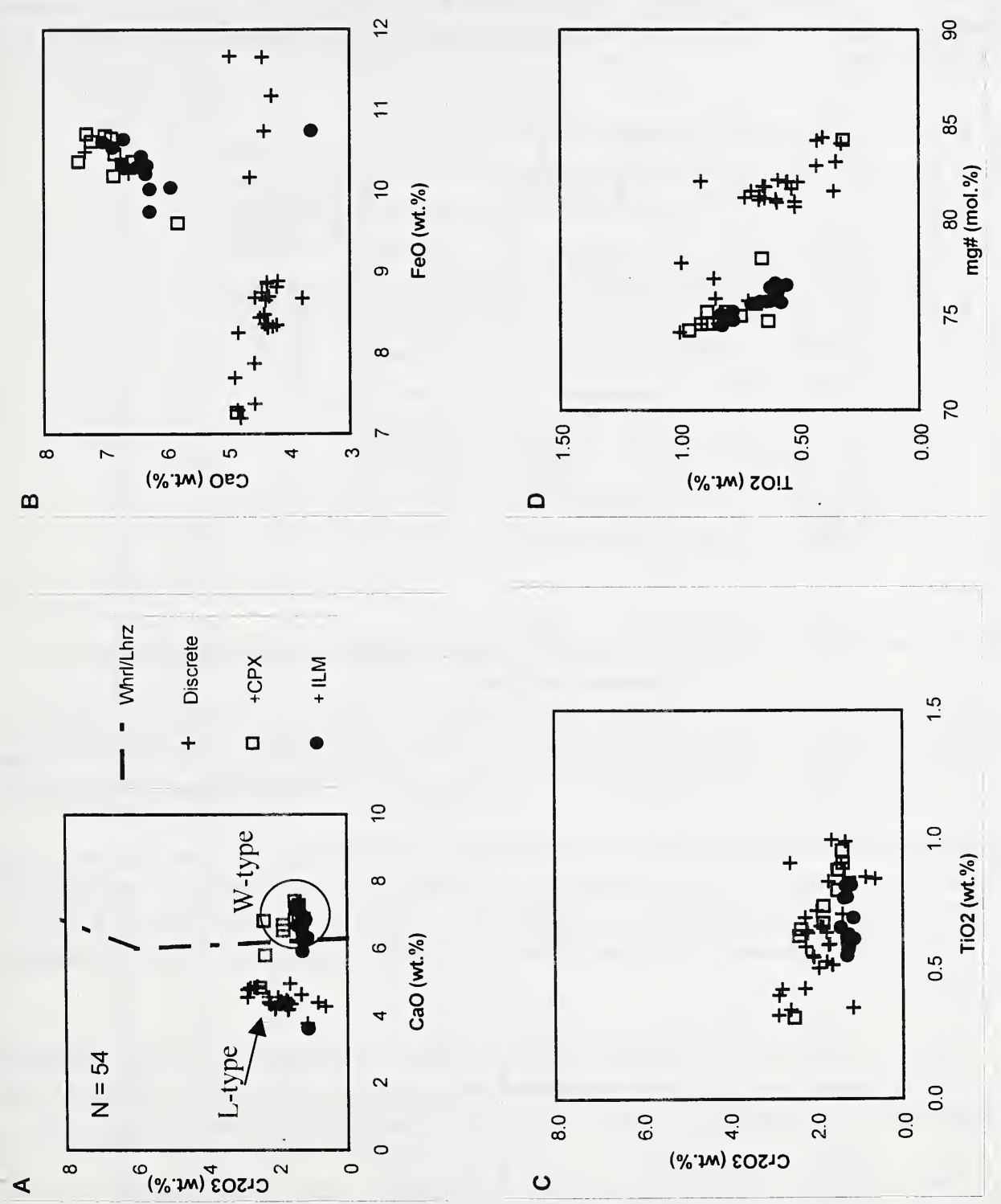